\title{
Triazole-containing monophosphate mRNA cap analogs as effective translation inhibitors
}

\author{
KAROLINA PIECYK, ${ }^{1}$ MACIEJ LUKASZEWICZ, ${ }^{2}$ EDWARD DARZYNKIEWICZ, ${ }^{2,3}$ \\ and MARZENA JANKOWSKA-ANYSZKA ${ }^{1}$ \\ ${ }^{1}$ Faculty of Chemistry, University of Warsaw, 02-093, Warsaw, Poland \\ ${ }^{2}$ Division of Biophysics, Institute of Experimental Physics, Faculty of Physics, University of Warsaw, 02-089, Warsaw, Poland \\ ${ }^{3}$ Centre of New Technologies, University of Warsaw, 02-097, Warsaw, Poland
}

\begin{abstract}
Synthetic analogs of the $5^{\prime}$ end of mRNA (cap structure) are widely used in molecular studies on mechanisms of cellular processes such as translation, intracellular transport, splicing, and turnover. The best-characterized cap binding protein is translation initiation factor $4 \mathrm{E}$ (eIF4E). Recognition of the mRNA cap by elF4E is a critical, rate-limiting step for efficient translation initiation and is considered a major target for anticancer therapy. Here, we report a facile methodology for the preparation of N2-triazole-containing monophosphate cap analogs and present their biological evaluation as inhibitors of protein synthesis. Five analogs possessing this unique hetero-cyclic ring spaced from the $\mathrm{m} 7$-guanine of the cap structure at a distance of one or three carbon atoms and/or additionally substituted by various groups containing the benzene ring were synthesized. All obtained compounds turned out to be effective translation inhibitors with $\mathrm{IC}_{50}$ similar to dinucleotide triphosphate $\mathrm{m}^{7} \mathrm{GpppG}$. As these compounds possess a reduced number of phosphate groups and, thereby, a negative charge, which may support their cell penetration, this type of cap analog might be promising in terms of designing new potential therapeutic molecules. In addition, an exemplary dinucleotide from a corresponding mononucleotide containing benzyl substituted 1,2,3-triazole was prepared and examined. The superior inhibitory properties of this analog (10-fold vs. $\left.\mathrm{m}^{7} \mathrm{GpppG}\right)$ suggest the usefulness of such compounds for the preparation of mRNA transcripts with high translational activity.
\end{abstract}

Keywords: mRNA; cap-dependent translation; translation inhibitor; cap analog; click chemistry; 1,2,3-triazole

\section{INTRODUCTION}

All cellular eukaryotic mRNAs have at their $5^{\prime}$ end a unique $\mathrm{m}^{7}$ GpppN cap structure (Fig. 1) composed of a 7-methylguanosine connected with the first transcribed nucleotide $(\mathrm{N})$ via a $5^{\prime}, 5^{\prime}$-triphosphate bridge (Furuichi and Shatkin 2000). The cap plays a crucial role in several cellular processes, such as pre-mRNA splicing (Sharp 1994), transport of RNA from the nucleus to the cytoplasm (Lewis and Izaurralde 1997), protection of mRNA against degradation (Rhoads 1985), and translation initiation (Gingras et al. 1999). Over the years, chemically modified cap analogs have been used for biochemical, biophysical, and structural studies on mechanisms of the aforementioned processes (Niedzwiecka et al. 2002; Grudzien et al. 2004; Jankowska-Anyszka et al. 2011; Ziemniak et al. 2013). So far, some of the most intense research directed toward the application of synthetic cap analogs has been focused on designing translation inhibitors that prevent binding of mRNA to eIF4E. Interaction of the eukaryotic initiation factor $4 \mathrm{E}$ (eIF4E) with the mRNA cap

Corresponding author: marzena@chem.uw.edu.pl

Article published online ahead of print. Article and publication date are at http://www.rnajournal.org/cgi/doi/10.1261/rna.046193.114. structure is crucial and a rate-limiting step of protein synthesis (Sonenberg 1996; Rhoads 2009). Under physiological conditions, the cellular level of eIF4E is low, which constitutes one of the mechanisms enabling regulation of gene expression at the translational level. The idea of using cap analogs for therapeutic purposes emerged with reports that an elevated level of eIF4E is associated with tumor formation and progression in human malignancies and cancers of the breast, colon, bladder, prostate, lung, head, and neck (Clemens and Bommer 1999; De Benedetti and Graff 2004; Mamane et al. 2004). As the cap is essential for efficient binding with the eIF4E protein, to date several structural features for the effectiveness of this interaction have been determined (Darzynkiewicz et al. 1985; Carberry et al. 1990; Marcotrigiano et al. 1997; Matsuo et al. 1997; Cai et al. 1999; Shen et al. 2001). It was shown that elements such as (1) the positive charge of the imidazole ring of guanosine, (2) the presence of at least two negative charges (or a negative charge and

() 2014 Piecyk et al. This article is distributed exclusively by the RNA Society for the first 12 months after the full-issue publication date (see http://rnajournal.cshlp.org/site/misc/terms.xhtml). After 12 months, it is available under a Creative Commons License (Attribution-NonCommercial 4.0 International), as described at http://creativecommons.org/licenses/ by-nc/4.0/. 


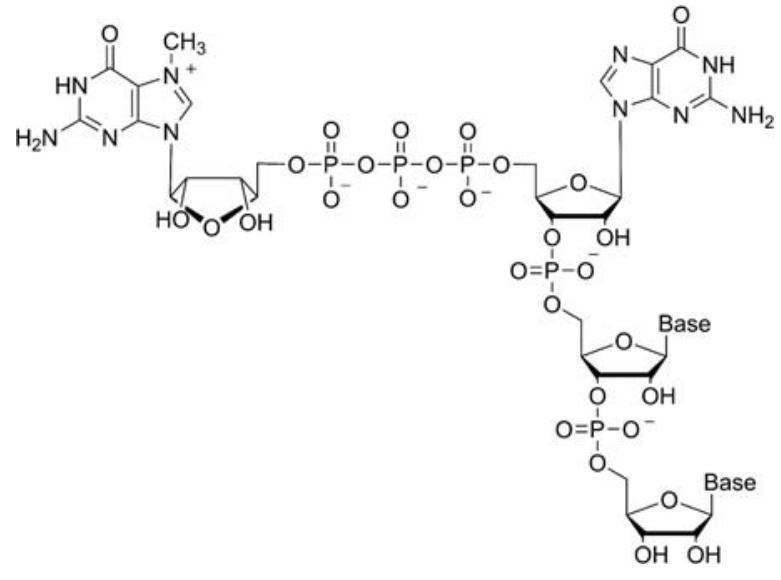

FIGURE 1. mRNA cap structure.

the free electron pair) within the phosphate chain, and (3) the presence of at least one hydrogen atom on the amino group of the 7-methyloguanosine should be preserved in order to synthesize an efficient translation inhibitor. To date, numerous modified cap analogs have been tested as inhibitors of cap-dependent translation in vitro by competing with mRNA for the binding site of eIF4E (Cai et al. 1999; Grudzien et al. 2004; Ghosh et al. 2005; Jia et al. 2010; Piecyk et al. 2012; Ziemniak et al. 2013). Unfortunately, due to their charged nature, in vivo application of such analogs is strictly limited. The first step to circumvent this problem might be designing nucleotide analogs with the least phosphate groups possible (mononucleotides monophosphates) that possess other, e.g., base modifications that provide an efficient level of inhibition. It was previously shown that a single substitution at the $\mathrm{N} 2$ position of the first (methylated) guanine moiety leads to increased translation inhibition (Cai et al. 1999). Based on these findings, we decided to introduce a new type of N2 substituents and evaluate the ability of obtained monophosphate analogs to inhibit the cap-dependent translation. We have chosen triazole-based groups as they not only exhibit excellent biological properties in the context of medicinal chemistry (Tron et al. 2008; Hein and Fokin 2010) but are also stable to oxidation and reduction and resistant to metabolic degradation (De las Heras et al. 1979). In this report, we describe the synthetic route for the preparation of N2-triazole-containing 7-methylguanosine-5' -monophosphates (mononucleotide cap analogs), and their biological evaluation as effective inhibitors of a cap-dependent translation. These types of compounds have not been described so far in the chemistry of mRNA cap analogs and have not been evaluated in vitro.

\section{RESULTS AND DISCUSSION}

\section{Chemical synthesis}

The triazole ring that was planned to be introduced within cap analogs can be easily generated by a copper (I) catalyzed version of the Huisgen 1,3 dipolar cycloaddition (CuAAC) between azides and terminal alkynes, which is one of the most popular "click chemistry" methodologies. This highly versatile reaction requiring mild conditions has gained over the past years enormous attention in pharmaceutical sciences and drug discovery (Soltis et al. 1996; Johnson et al. 2008; Huang et al. 2013). During the past few years, a burst in the number of publications on the topic has occurred; likewise, in the area of nucleic acids, the CuAAC chemistry has been used to synthesize a number of modified nucleosides, nucleotides, and oligonucleotides for a broad range of applications (Ami and Fujimoto 2008; Seela and Sirivolu 2008; Seela et al. 2008; Amblard et al. 2009; El-Sagheer and Brown 2010). The widespread use of the CuAAC reaction is associated with the fact that both alkyne and azide functional groups can be incorporated into a wide range of compounds by several general methods. As a result of this, various strategies for the preparation of cap analogs containing 1,2,3triazole substituents at the N2 position may be theoretically applied. Analyzing all technical aspects for the synthesis of such derivatives having this unique hetero-cyclic triazole ring (1) directly adjacent to the guanine ring, (2) spaced from the purine ring at a distance of one or three carbon atoms, or (3) additionally substituted by another aromatic ring such as benzene, we decided to explore whether a reliable efficient $\operatorname{method}(\mathrm{s})$ for their preparation could be found. Therefore, to synthesize guanosine analogs containing a triazole ring directly adjacent to the purine ring, we planned to introduce an azide group at the guanine N2 position through direct substitution of an appropriate intermediate (2) and subsequently perform the CuAAC reaction (Supplemental Scheme S1). Thus, guanosine was converted to its fully (ribose and $\mathrm{O} 6$ guanine) protected analog (1) through O-acylation and the Mitsunobu reaction, followed by introduction of the fluorine atom under anhydrous conditions with $t$-butyl nitrite $(\mathrm{BuONO})$ as the diazotizing agent and HF as the fluoride source (Scheme 1; Piecyk et al. 2012). The obtained 2fluoroinosine (2) was subjected to nucleophilic substitution with sodium azide. Unfortunately, the preparation of 2-azidoinosine was unsatisfactory, so we postulated that it might have been a consequence of spontaneous cyclization of azide substituted $\pi$-deficient nitrogen hetero-cycles to the corresponding fused tetrazole (Supplemental Fig. S1; Johnson et al. 1958; Temple et al. 1966a,b). It was previously speculated that some of the lower-yielding azide-alkyne ligations involving a C-2 azidopurine nucleoside could be due to the presence of the tetrazolyl tautomer (Amblard et al. 2009), and it was shown that the tetrazole-azide equilibrium depends on the temperature and the solvent polarity (Lakshman et al. 2010). Given these unsatisfactory results of obtaining 2-azidoinosine, we considered another route to triazole-containing cap analogs using the methodology shown in Scheme 2. We decided to perform a 1,3-dipolar cycloaddition reaction at the final stage of the synthesis using as substrates the methylated nucleotides possessing pent-4-ynyl 


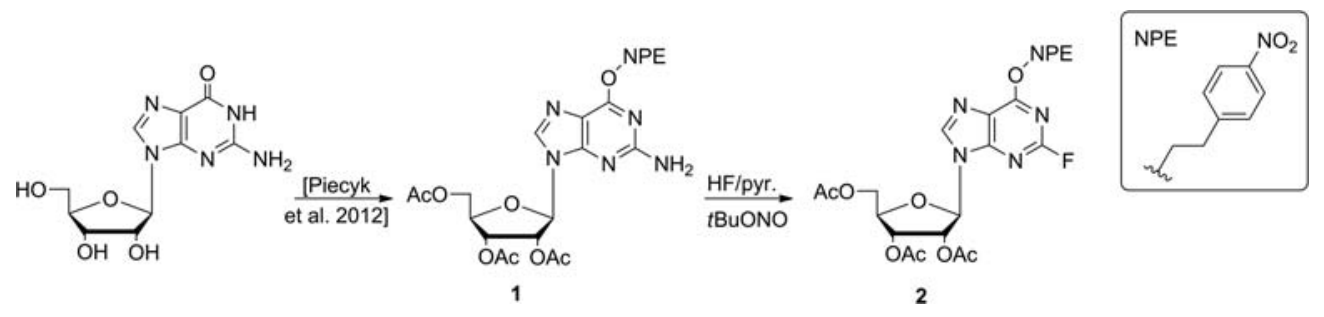

SCHEME 1. Synthesis of the $\mathrm{N}^{2}$-fluoro- $2^{\prime}, 3^{\prime}, 5^{\prime}$-O-triacetyl- $\mathrm{O}^{6}-$ [2-(4-nitrophenyl)ethyl]inosine.

or propargyl substituent at the $\mathrm{N} 2$ position and one of five selected azide derivatives (Fig. 2). For this, we used 2-fluoroinosine (2) as a starting material and performed a substitution reaction with propargyl amine or pent-4-yn-1-amine, leading to $\mathbf{3} \mathbf{a}$ and $\mathbf{3} \mathbf{b}$, respectively and their selective deprotection (Scheme 2). Subsequently, the N2-modified guanosine derivatives (3) were 5'-phosphorylated (Scheme 3) using the Yoshikawa method (Yoshikawa et al. 1967) with phosphorus oxide trichloride in trimethyl phosphate at $4^{\circ} \mathrm{C}$ (giving $4 \mathbf{a}-\mathbf{b}$ ) and further methylated at the $N^{7}$ position of the guanine ring with $\mathrm{CH}_{3} \mathrm{I}$ in DMSO at RT, leading to compounds $\mathbf{5 a - b}$. Purification of the analogs was done using ion-exchange chromatography on DEAE-Sephadex A-25 ( $\mathrm{HCO}_{3}^{-}$form). The obtained mononucleotides and selected azides (Fig. 2) were converted into triazole-containing analogs via a "click" reaction (Scheme 3). Due to the fact that the substrates $(\mathbf{5} \mathbf{a}-\mathbf{b})$ and reaction products $(\mathbf{6 a - e})$ had exactly the same negative net charge, separation of the final products from the reaction mixtures using ion-exchange chromatography may have become problematic. In order to assure quantitative conversion of substrates into desired products, several trials were conducted to determine optimal reaction conditions such as solvent, copper ion concentration, reaction time, and temperature. Among all tested reaction parameters, DMF with a small amount of $\mathrm{H}_{2} \mathrm{O}$ ensuring complete dissolution of the reagents, a temperature of $50^{\circ} \mathrm{C}$, and the concentration of copper ions 1.3 eq. in relation to the nucleotide turned out to be the most effective. Another important factor that allowed us to obtain efficiently triazole-containing cap analogs was usage as a coupling reaction catalyst Tris[(1-benzyl-1H1,2,3-triazol-4-yl)methyl] amine (TBTA) (Chan et al. 2004). This polytriazolylamine ligand stabilized $\mathrm{Cu}(\mathrm{I})$ toward disproportionation and oxidation and, thus, enhanced its catalytic effect. The conducted experiments have shown that, regardless of the azide used, the reaction proceeded quantitatively when suitable coupling conditions, argon atmosphere, and TBTA were applied. In this manner, five new cap analogs containing the triazole ring at the $\mathrm{N} 2$ position $(\mathbf{6 a}-\mathbf{e})$ (Table 1) were obtained and purified on ion-exchange DEAESephadex resin. The structure and homogeneity of final products were confirmed by HPLC, MS, ${ }^{1} \mathrm{H}$ NMR, and ${ }^{31} \mathrm{P}$ NMR. For biological studies, compounds 6a-e were subsequently rechromatographed on a semipreparative reversedphase HPLC column and isolated as ammonium salts.

Given these satisfactory results, we managed to develop a methodology that simplifies the synthesis, assures higher solubility of intermediates in solvents used in the "click" reaction, and eases product isolation and purification. Based on biological data described in the next paragraph, one of the mononucleotide cap analogs (6b) was converted into its dinucleotide counterpart (7). For the preparation of the desired compound, we used the well-known strategy in which the triphosphate bridge is created via a reaction between two mononucleotide units, one of which has been converted to a reactive imidazolide derivative (Kadokura et al. 1997). For this, in the first step, the imidazolide derivative of GDP (imGDP) was prepared through reaction with imidazole in the presence of 2,2'-dithiodipyridine and triphenylphosphine. Subsequently, the resultant imGDP was coupled with compound $\mathbf{6 b}$ in anhydrous conditions in the presence of zinc ions, giving dinucleotide 7 (Supplemental Scheme S2).

\section{Biology}

To evaluate the ability of newly synthesized triazole-containing monophosphates to inhibit cap-dependent translation in a cell-free translation system, the previously reported procedure was used (Kowalska et al. 2009). The chosen method,

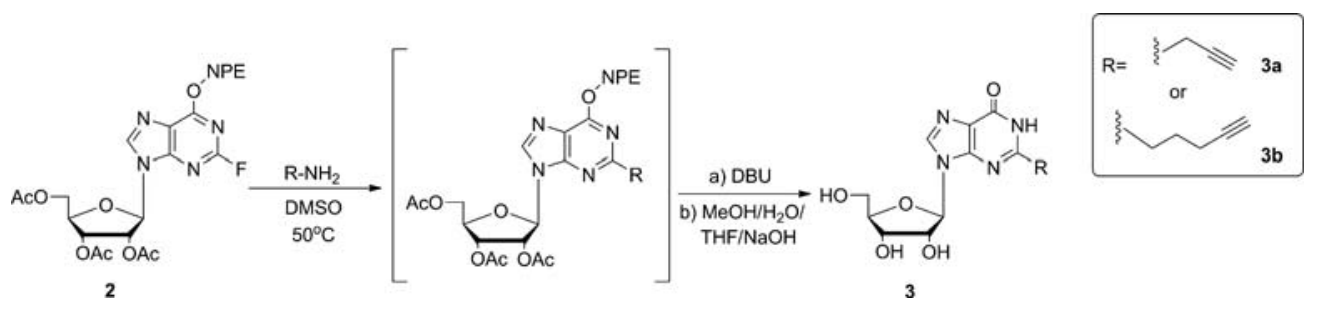

SCHEME 2. Preparation of N2 modified guanosine derivatives containing alkynyl substituents. 
$\mathrm{NaN}_{3}$

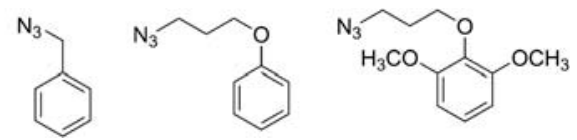

FIGURE 2. Azides used for the "click" reaction.

although less direct than binding in a purified system, is preferred as it mimics competition between the cap analog and mRNA in a system containing all natural components. Briefly, experiments were performed in a micrococcal nuclease-treated rabbit reticulocyte lysate using an in vitro-transcribed, ARCA-capped, $\beta$-globin 5' UTR containing mRNA encoding firefly luciferase to allow determination of protein synthesis by luminometry. Three standard cap analogs were used as controls in the experiments. $\mathrm{m}^{7} \mathrm{GTP}$ and $\mathrm{m}^{7} \mathrm{GpppG}$ were positive controls, as both are known to be effective translation inhibitors in various cell-free systems (Cai et al. 1999; Grudzien et al. 2004), and $m^{7}$ GMP was a negative control that has very little or no inhibitory capacity (Cai et al. 1999). It is well known that the largest determinants of inhibitory activity for $\mathrm{m}^{7} \mathrm{G}$ cap analogs are the phosphate groups (Cai et al. 1999). The strength of translation inhibition increases $\sim 20$-fold for $\mathrm{m}^{7} \mathrm{GpppG}$ and $\sim 50$-fold for $\mathrm{m}^{7} \mathrm{GTP}$ as compared to $\mathrm{m}^{7} \mathrm{GMP}$.

In the present work, we reveal that synthesized triazolecontaining monophosphate cap analogs efficiently inhibit translation similarly to $\mathrm{m}^{7} \mathrm{GpppG}$. These results are promising in the context of designing new cap analogs that can be used as novel inhibitors of protein synthesis. We have observed that, in general, presence of a triazole ring within the $\mathrm{N} 2$ position of a guanine ring is sufficient to make a simple $5^{\prime}$-monophosphate cap analog a good translation inhibitor (Fig. 3). The determined $\mathrm{IC}_{50}$ values (Table 1) are relatively similar for all tested analogs; nevertheless, some trends can be definitely outlined.

The first explored factor was the distance between the triazole ring and the purine base and its influence on the ability of cap analogs to inhibit cap-dependent translation. Two (6b and $6 \mathbf{6 e}$ ) out of five analogs were designed to differ only in the number of carbon atoms spacing both rings (one and three, respectively). Comparing $\mathrm{IC}_{50}$ values for compounds $\mathbf{6} \mathbf{b}$ and $6 e$, only a slight increase in inhibitory properties of the analog $\mathbf{6 b}$ vs. $6 \mathrm{e}$ was observed. This may suggest that the spacer length does not have a great impact on the effectiveness of cap analogs as translation inhibitors. A clear improvement of inhibitory properties was observed for compounds with the substituted triazole ring $(\mathbf{6 b}-\mathbf{d})$ as compared to compound 6a. Interestingly, introduction of an additional oxygen hetero-atom close to the benzene ring affected considerably the ability of the cap analog to inhibit translation (about twofold for $\mathbf{6 c}$ and $\mathbf{6 d}$ vs. $\mathbf{6 b}$ ). Introduction of further electro-donor substituents (e.g., methoxy) into the benzene ring did not decrease the $\mathrm{IC}_{50}$ value. Out of all tested monophosphate analogs, the best properties were observed for compounds $\mathbf{6 c}$ and $\mathbf{6 d}$. Designated $\mathrm{IC}_{50}$ values for these compounds indicated that the strength of inhibition is similar to $\mathrm{m}^{7} \mathrm{GTP}$ which is known and used as a good translation inhibitor, and it is at least 10 times higher than for the corresponding 7-methylated monophosphate ( $\left.\mathrm{m}^{7} \mathrm{GMP}\right)$. The performed studies suggest that an appropriate substituent at the N2 position of guanine compensates for the absence of the two phosphate groups. As a consequence, the net negative charge of the cap analogs - a key factor related to the inability of compounds to cross the cell membrane-is decreased.

Taking all this into account, we decided to explore the effect of the N2 modification within the guanine ring on the inhibitory properties of the dinucleotide cap analog. This idea has appeared due to the fact that, in the case of analogs having various modifications at the N7 position, it was shown that, while the presence of a suitable substituent (e.g., benzyl or p-chlorobenzyl) caused increased (several fold) inhibitory properties of mononucleotide monophosphates, this effect was no longer visible for the corresponding dinucleotide triphosphates (Cai et al. 1999). To perform these studies, we

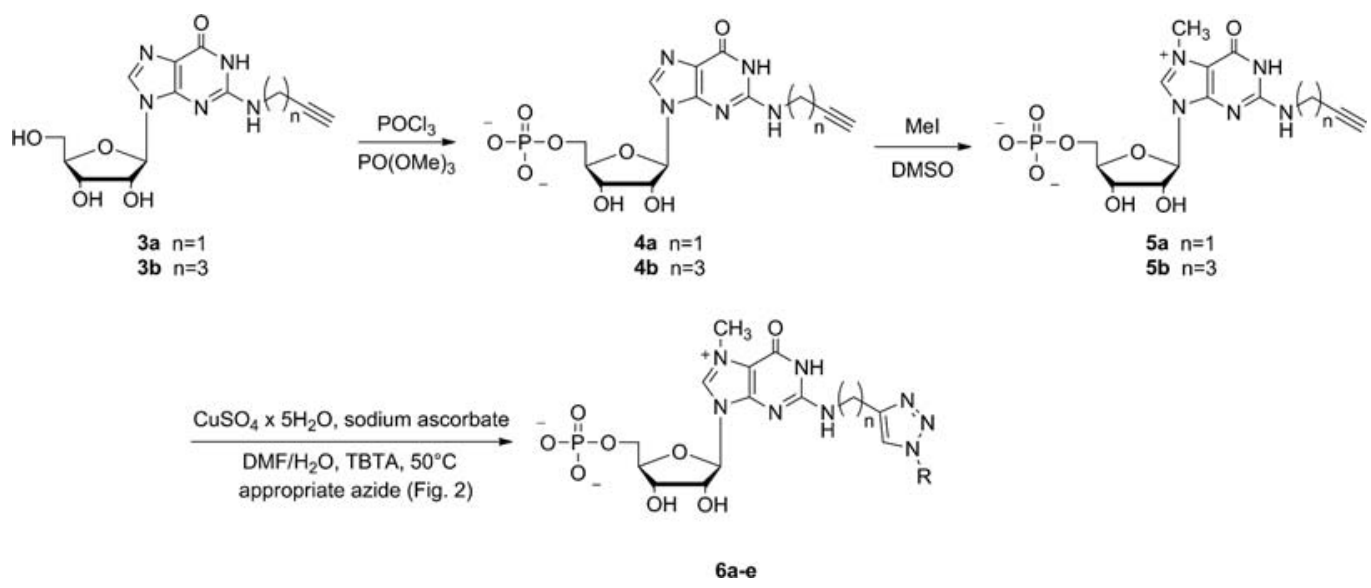

SCHEME 3. Synthesis of triazole-containing cap analogs. 
TABLE 1. Inhibition of translation in rabbit reticulocyte lysate extract by N2-modified cap analogs

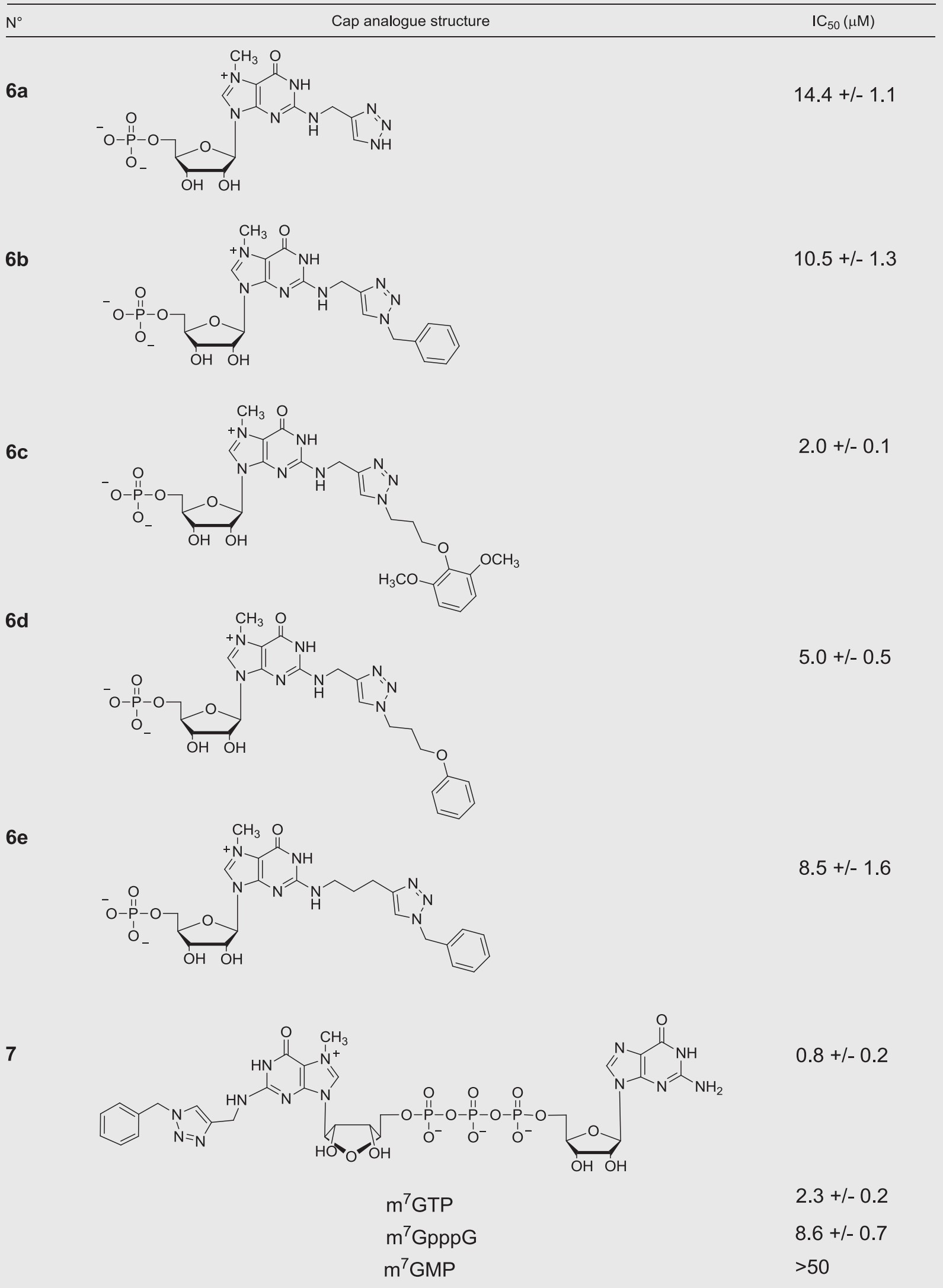


decided to convert compound $\mathbf{6 b}$ into a dinucleotide (7) and test it analogously as monophosphates. It turned out that the obtained analog exhibited superior inhibitory properties ( $\sim 10$-fold vs. 6c and threefold vs. $\left.\mathrm{m}^{7} \mathrm{GTP}\right)$. This observation emphasizes that the character of the modifications at the N7 and N2 positions is diverse and the influence of the N2 substituents on the ability of the cap analog to inhibit protein synthesis, as opposed to analogs modified at the N7 position, can still be beneficial for both mono- and dinucleotides.

In conclusion, the obtained analogs are good translation inhibitors and can be used as potential therapeutics in the future due to the fact that they possess a reduced number of phosphate groups, which may support their cell penetration. In addition to that, superior inhibitory properties for the examined dinucleotide analog suggest that this type of compound (N2 modified) may also be useful for a preparation of mRNA transcripts with high translational activity.

\section{MATERIALS AND METHODS}

\section{Inhibition of cap-dependent translation in vitro in $\mathbf{R R L}$}

An inhibition assay of the cap-dependent translation in vitro in a micrococcal nuclease-treated RRL lysate (Flexi Rabbit Reticulocyte Lysate System, Promega) was performed as previously described (Kowalska et al. 2009).

A typical translation reaction contained: $56 \%$ of RRL lysate, 0.01 $\mathrm{mM}$ amino acids mixture, 0.32 units/ $\mu \mathrm{L}$ RiboLock Ribonuclease Inhibitor (Fementas), magnesium acetate, potassium acetate, and $\mathrm{m}_{2}^{7,3^{\prime}}$ OGpppG-capped (Stepinski et al. 2001) luciferase mRNA transcript (in $12.5 \mu \mathrm{L}$ final volume). Capped and polyadenylated luciferase mRNAs were obtained via transcription in vitro with SP6 RNA polymerase on the dsDNA template encoding: $5^{\prime}$ UTR sequence of rabbit $\beta$-globin mRNA following by the firefly luciferase ORF and a stretch of 31 adenines. The obtained RNA transcripts, after removal of DNA template with RQ1 DNAse (Promega), were purified using
NucAway Spin columns (Ambion) and used in the translation reactions in RRL at a final concentration $5 \mathrm{ng} / \mu \mathrm{L}$. Optimal conditions for cap-dependent translation in vitro in the used batch of Flexi RRL lysate (3.2 mM concentration of endogenous $\mathrm{Mg}^{2+}$ ) were achieved at $0.6 \mathrm{mM}$ concentration of magnesium acetate and 210 $\mathrm{mM}$ of potassium acetate. At these conditions, ApppG-capped luciferase RNA showed minimal translational activity that was insensitive to inhibition with the $\mathrm{m}^{7} \mathrm{GpppG}$ cap analog (Supplemental Fig. 2). Translation reactions were pre-incubated at $30^{\circ} \mathrm{C}$ for 60 min prior to addition of luciferase mRNA and appropriate dilution of a tested cap analog, and incubated further at $30^{\circ} \mathrm{C}$. Reactions were stopped after $60 \mathrm{~min}$ after addition of mRNA by chilling on ice. The pre-incubation step was described in Kowalska et al. (2009) and was used in all of the further experiments that were performed in our lab. Using the same conditions allows comparison of data obtained for various cap analogs. To measure the luciferase activity, $2.5 \mu \mathrm{L}$ of the translation reaction was mixed with $40 \mu \mathrm{L}$ of Luciferase Assay Reagent (Promega), and a luminescence signal was detected in a luminometer (Glomax, Promega). The obtained data were used to determine $\mathrm{IC}_{50}$ values for inhibition of cap-dependent translation by cap analogs as previously described (Kowalska et al. 2009).

\section{Chemical synthesis}

All used reagents were purchased in the highest available purity from Sigma-Aldrich Chemical Co. and were used without any further treatment, except for the benzyl azides, which were prepared by treating the corresponding benzyl bromides with $\mathrm{NaN}_{3}$ in DMF. TLC analysis for N2 modified nucleosides was performed on TLC plates coated with silicagel 60 F-254 (Merck), developed in methylene chloride-methanol-triethylamine 9:1:0.1 (v/v/v). Triethylammonium bicarbonate (TEAB) buffer was prepared by bubbling $\mathrm{CO}_{2}$ through an ice-cold aqueous solution of redistilled triethylamine. Intermediate nucleotides and final products were separated by ion-exchange chromatography on a DEAE-Sephadex A-25 $\left(\mathrm{HCO}_{3}^{-}\right.$form) using a linear gradient of TEAB buffer ( $\mathrm{pH}$ 7.6). Fractions containing products were combined, evaporated under reduced pressure with several additions of ethanol, and isolated as
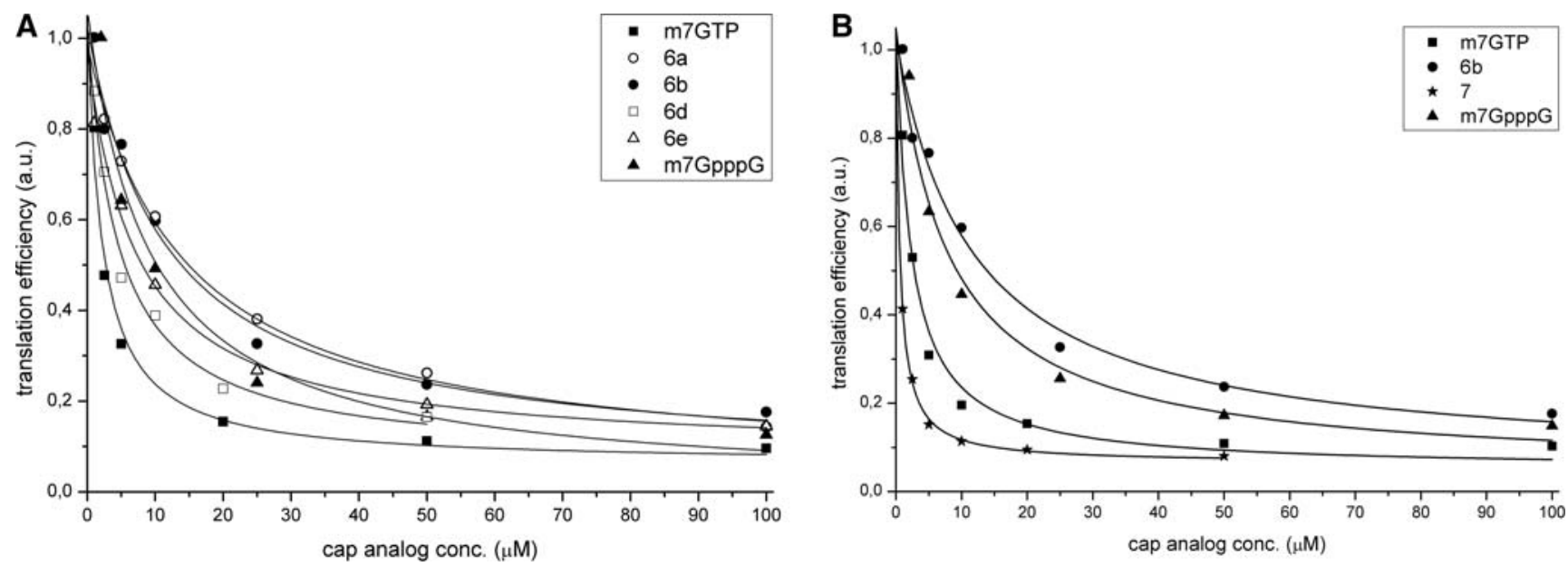

FIGURE 3. Inhibition of $\mathrm{m}_{2}^{7,3^{\prime} \mathrm{O}} \mathrm{GpppG}$-capped-luciferase mRNA translation in RRL lysate by novel $\mathrm{N}^{2}$-substituted $\mathrm{m}^{7} \mathrm{GMP}$ analogs: $(A, B) \mathbf{6 b}(\mathbf{0})$, $\mathbf{6 a}$ $(\bigcirc), 6 \mathbf{e}(\Delta)$, and $\mathbf{6 d}(\square)$. An example of inhibition by the dinucleotide cap analog $7(\star)$ derived from compound $\mathbf{6 b}$ is also shown $(B)$. Standard unmodified compounds $\mathrm{m}^{7} \mathrm{GTP}(\boldsymbol{\square})$ and $\mathrm{m}^{7} \mathrm{GpppG}(\boldsymbol{\Delta})$ are included as controls. The figure shows fitted curves to the experimental data points (as described in Materials and Methods). The unmodified $\mathrm{m}^{7} \mathrm{GMP}$ (up to $200 \mu \mathrm{M}$ ) does not inhibit cap-dependent translation in the same experimental set-up. 
triethylammonium salts (TEA salts). HPLC was performed on a Knauer instrument using a Supelcosil LC-18-T RP column $(4.6 \times$ $250 \mathrm{~mm}$, flow rate $1.0 \mathrm{~mL} \mathrm{~min}^{-1}$ ) with a linear gradient of methanol from $0 \%$ to $50 \%$ (v/v) in $0.05 \mathrm{M}$ ammonium acetate (pH 5.9). UV detection was performed at $254 \mathrm{~nm}$. Exact mass measurements were recorded on a Micromass QToF spectrometer using electrospray ionization. ${ }^{1} \mathrm{H}$ NMR spectra were recorded on a Varian INOVA 200 and $400 \mathrm{MHz}$ spectrometers using tetramethylsilane (TMS) as the internal standard in $\mathrm{CDCl}_{3}$ and sodium 3-trimethylsilyl[2,2,3,3-D4]-propinonate (TSP) in $\mathrm{D}_{2} \mathrm{O} .{ }^{31} \mathrm{P}$ NMR spectra were recorded on a Varian INOVA $200 \mathrm{MHz}$.

\section{$\mathrm{N}^{2}$-Fluoro-2', 3', 5' -O-triacetyl-O $\mathrm{O}^{6}$-[2-(4-nitrophenyl) ethyl] inosine (2)}

$2^{\prime}, 3^{\prime}, 5^{\prime}$-tri-O-acetyl-O ${ }^{6}$-[2-(4-nitrophenyl)ethyl] guanosine (1.0 g, $1.79 \mathrm{mmol}$ ) was dissolved in anhydrous pyridine $(6.75 \mathrm{~mL}, 0.082$ $\mathrm{mol}$ ) in a polypropylene tube under nitrogen atmosphere. The tube was cooled in a dry ice/acetonitrile bath $\left(-35^{\circ} \mathrm{C}\right)$ and $70 \%$ $\mathrm{HF} /$ pyridine solution $(12 \mathrm{~mL}, 0.42 \mathrm{~mol})$ was added dropwise. The reaction mixture was stirred for $15 \mathrm{~min}$, and $t$-butyl nitrite $(0.54$ $\mathrm{mL}, 4.5 \mathrm{mmol}$ ) was added. After $1 \mathrm{~h}$, the reaction was quenched at $0^{\circ} \mathrm{C}$ by pouring the reaction mixture into an aqueous $\mathrm{K}_{2} \mathrm{CO}_{3}$ solution ( $28.5 \mathrm{~g}$ in $25 \mathrm{~mL}$ of water) and extracted three times with ethyl acetate. The organic layers were collected, dried over anhydrous $\mathrm{Na}_{2} \mathrm{SO}_{4}$, and evaporated to dryness. Purification by column chromatography on silica gel using as eluent $60: 1(\mathrm{v} / \mathrm{v}) \mathrm{CH}_{2} \mathrm{Cl}_{2}: \mathrm{MeOH}$ gave $0.85 \mathrm{~g}(85 \%)$ of product; TLC silica gel, $\mathrm{CH}_{2} \mathrm{Cl}_{2}: \mathrm{MeOH}, 60: 1$ $\mathrm{R}_{\mathrm{F}}=0.4 ;{ }^{1} \mathrm{H}$ NMR $\left(700 \mathrm{MHz}, \mathrm{CDCl}_{3}\right) \delta 8.21-8.15(\mathrm{~m}, 2 \mathrm{H}, \mathrm{Ph})$, 8.08 (s, 1H, H-8), 7.50 (d, 2H, Ph), 6.13 (d, J=5.6 Hz, 1H, H-1'), $5.82\left(\mathrm{t}, J=4.9 \mathrm{~Hz}, 1 \mathrm{H}, \mathrm{H}-2^{\prime}\right), 5.60-5.55\left(\mathrm{~m}, 1 \mathrm{H}, \mathrm{H}-3^{\prime}\right), 4.84(\mathrm{t}, J$ $\left.=6.7 \mathrm{~Hz}, 2 \mathrm{H}, \mathrm{O}-\mathrm{CH}_{2}, \mathrm{NPE}\right), 4.46-4.42\left(\mathrm{~m}, 2 \mathrm{H}, \mathrm{H}-4^{\prime}, \mathrm{H}-5^{\prime}\right)$, $4.38-4.36\left(\mathrm{~m}, 1 \mathrm{H}, \mathrm{H}-5^{\prime \prime}\right), 3.32\left(\mathrm{t}, J=6.7 \mathrm{~Hz}, 2 \mathrm{H}, \mathrm{CH}_{2} \mathrm{Ph}, \mathrm{NPE}\right)$, $2.15\left(\mathrm{~s}, 6 \mathrm{H}, \mathrm{CH}_{3}\right.$, acetyl), $2.08\left(\mathrm{~s}, 3 \mathrm{H}, \mathrm{CH}_{3}\right.$, acetyl). ${ }^{13} \mathrm{C} \mathrm{NMR}$ $\left(200 \mathrm{MHz}, \mathrm{CDCl}_{3}\right) \delta 170.2(\mathrm{C}=\mathrm{O}), 169.5(\mathrm{C}=\mathrm{O}), 169.3(\mathrm{C}=\mathrm{O})$, 160.3, 159.3 (C-6), 154.2 (C-2), 147.1, 145.1, 140.8, $129.9(\mathrm{Ph})$, $123.8(\mathrm{Ph}), 86.4\left(\mathrm{C}-1^{\prime}\right), 80.5\left(\mathrm{C}-4^{\prime}\right), 73.0\left(\mathrm{C}-2^{\prime}\right), 72.4\left(\mathrm{C}-3^{\prime}\right), 67.7$ (OCH2, NPE), 62.8 (C-5'), $34.9(\mathrm{CH} 2 \mathrm{Ph}), 20.7$ (C, acetyl), 20.5 (C, acetyl), 20.3 (C, acetyl); m/z: calcd for C24H24FN5O10 (M $+\mathrm{H})^{+}: 562.1579$, found: 562.1581 .

\section{Procedure for the synthesis of N2-substituted derivatives $3 a-3 b$}

N2-fluoro-2' $3^{\prime}, 5^{\prime}$-O-triacetyl-O ${ }^{6}$-[2-(4-nitrophenyl)ethyl] inosine (2) $(250 \mathrm{mg}, 0.45 \mathrm{mmol})$ was dissolved in $2 \mathrm{~mL}$ of anhydrous dimethylsulfoxide (DMSO) and propargylamine $(0.9 \mathrm{mmol}, 58 \mu \mathrm{L})$ or pent-4yn-1-amine $(0.9 \mathrm{mmol}, 87 \mu \mathrm{L})$ was added. The reaction mixture was stirred at $60^{\circ} \mathrm{C}$ until the fluoronucleoside completely disappeared (TLC). Next, $0.5 \mathrm{M} \mathrm{NaOH}$ in THF/MeOH/H$/ \mathrm{H}_{2} \mathrm{O}$ (5:4:2) was added and stirred at room temperature until the full deprotection of nucleoside was observed based on TLC. The solvent was removed under high vacuum, and the resulting oily residue was purified by column chromatography on Diaion HP-20 using for elution water with a linear gradient of methanol from $0 \%$ to $40 \%$ (v/v). Fractions containing product were collected, evaporated, and dried over $\mathrm{P}_{4} \mathrm{O}_{10}$ to yield:

$\mathrm{N}^{2}$-(prop-2-ynyl)guanosine (3a); 70\%, $0.315 \mathrm{mmol}, 102 \mathrm{mg}$; $\left(200 \mathrm{MHz}, \mathrm{D}_{2} \mathrm{O}\right) \delta 7.80(\mathrm{~s}, 1 \mathrm{H}, \mathrm{H}-8), 6.13(\mathrm{~d}, J=4.8 \mathrm{~Hz}, 1 \mathrm{H}$,
$\left.\mathrm{H}-1^{\prime}\right)$, 4.75-4.73 (m, 1H, H-2'), 4.48-4.45 (m, 1H, H-3'), 4.24$4.19\left(\mathrm{~m}, 2 \mathrm{H}, \mathrm{NH}-\mathrm{CH}_{2}\right), 4.39-4.35\left(\mathrm{~m}, 1 \mathrm{H}, \mathrm{H}-4^{\prime}\right), 4.24-4.19$ (m, 1H, H-5'), 4.06-4.04 (m, 1H, H-5"), 4.09 (s, 3H, N7- $\mathrm{CH}_{3}$ ), 2.64-2.63 (t, 1H, CHC); m/z: $(\mathrm{M}+\mathrm{H})^{+}: 322.1608$.

$\mathrm{N}^{2}$-(pent-4-yn-1-yl)guanosine (3b); 68\%, $0.306 \mathrm{mmol}, 107 \mathrm{mg}$; $\left(200 \mathrm{MHz}, \mathrm{D}_{2} \mathrm{O}\right) \delta 7.76(\mathrm{~s}, 1 \mathrm{H}, \mathrm{H}-8), 6.12(\mathrm{~d}, J=4.7 \mathrm{~Hz}, 1 \mathrm{H}, \mathrm{H}-$ $\left.1^{\prime}\right)$, 4.69-4.66 (m, 1H, H-2'), 4.45-4.42 (m, 1H, H-3'), 4.37-4.34 (m, $\left.1 \mathrm{H}, \mathrm{H}-4^{\prime}\right), 4.23-4.18\left(\mathrm{~m}, 1 \mathrm{H}, \mathrm{H}-5^{\prime}\right), 4.08-4.03\left(\mathrm{~m}, 1 \mathrm{H}, \mathrm{H}-5^{\prime \prime}\right)$, $4.06\left(\mathrm{~s}, 3 \mathrm{H}, \mathrm{N} 7-\mathrm{CH}_{3}\right), 3.55-3.51\left(\mathrm{t}, 2 \mathrm{H}, \mathrm{NH}-\mathrm{CH}_{2}\right), 2.34-2.35$ (t, 1H, CHC), 2.30-2.26 (m, 2H, NH- $\left.\mathrm{CH}_{2}-\mathrm{CH}_{2}-\mathrm{CH}_{2}\right), 1.85-1.79$ (quin, $\left.2 \mathrm{H}, \mathrm{NH}-\mathrm{CH}_{2}-\mathrm{CH}_{2}-\mathrm{CH}_{2}\right) ; \mathrm{m} / \mathrm{z}:(\mathrm{M}+\mathrm{H})^{+}: 350.0777$.

\section{Procedure for the synthesis of the N7 methylated N2 modified 5'-monophosphates $5 a-5 b$}

Phosphorus oxide trichloride $\left(\mathrm{POCl}_{3}\right)(1.1 \mathrm{mmol}, 103 \mu \mathrm{L})$ and trimethyl phosphate $(0.018 \mathrm{~mol}, 2.15 \mathrm{~mL})$ were cooled to $4^{\circ} \mathrm{C}$ and added to the dried compounds $3 \mathbf{a}(0.31 \mathrm{mmol}, 100 \mathrm{mg})$ or $3 \mathbf{b}(0.31$ mmol, $109 \mathrm{mg}$ ). The reaction mixtures were stirred at $4^{\circ} \mathrm{C}$ for 3 h. The solutions were allowed to warm to RT, and $1.0 \mathrm{M}$ aqueous $\mathrm{TEAB}$ was added to maintain the $\mathrm{pH}$ as neutral. Products were purified by ion-exchange chromatography on a DEAE-Sephadex A- 25 column using a linear $0-1 \mathrm{M}$ TEAB gradient to produce products $\mathbf{4 a}-\mathbf{4 b}$ as TEA salts. Compounds $\mathbf{4 a}$ and $\mathbf{4 b}$ were used directly for the methylation reaction. To the suspension of $0.28 \mathrm{mmol}$ of mononucleotide derivatives $\mathbf{4 a}(112 \mathrm{mg})$ or $\mathbf{4 b}(120 \mathrm{mg})$ in $1.5 \mathrm{~mL}$ anhydrous dimethylsulfoxide, methyl iodide $(1.4 \mathrm{mmol}, 87 \mu \mathrm{L})$ was added. The reaction mixtures were stirred at room temperature for $2 \mathrm{~h}$ and then were poured into the water $(6 \mathrm{~mL})$ and extracted several times with diethyl ether $(\sim 5 \times 6 \mathrm{~mL})$. The aqueous phases were purified on DEAE-Sephadex using a linear 0-0.8 M gradient of TEAB. Additionally, both nucleotides were purified on reversed-phase HPLC column. Products were lyophilized to yield:

$\mathrm{N}^{2}$-(prop-2-ynyl)-7-methylguanosine-5'-monophosphate (5a); $0.185 \mathrm{mmol} 59 \%$, $78 \mathrm{mg} ;{ }^{1} \mathrm{H}$ NMR $\left(400 \mathrm{MHz}, \mathrm{D}_{2} \mathrm{O}\right) \delta 6.13(\mathrm{~d}$, $\left.J=3.2 \mathrm{~Hz}, 1 \mathrm{H}, \mathrm{H}-1^{\prime}\right), 4.75-4.73\left(\mathrm{~m}, 1 \mathrm{H}, \mathrm{H}-2^{\prime}\right), 4.48-4.45(\mathrm{~m}$, $\left.1 \mathrm{H}, \mathrm{H}-3^{\prime}\right)$, 4.39-4.35 (m, 1H, H-4'), 4.24-4.19 (m, 3H, $\mathrm{NHCH}_{2}$, $\left.\mathrm{H}-5^{\prime}\right), 4.09$ (s, 3H, N7-CH $\left.\mathrm{CH}_{3}\right), 4.06-4.04\left(\mathrm{~m}, 1 \mathrm{H}, \mathrm{H}-5^{\prime \prime}\right), 2.63(\mathrm{t}$, $J=2.5 \mathrm{~Hz}, 1 \mathrm{H}, \mathrm{CCH}) ;{ }^{31} \mathrm{P}$ NMR $\left(283 \mathrm{MHz}, \mathrm{D}_{2} \mathrm{O}\right) \delta 1.527 ; \mathrm{m} / \mathrm{z}$ : $(\mathrm{M}+\mathrm{H})+:$ 416.0937; $\mathrm{t}_{\mathrm{R}} 13 \mathrm{~min}$.

$\mathrm{N}^{2}$-(pent-4-yn-1-yl)-7-methylguanosine-5' -monophosphate (5b); $0.162 \mathrm{mmol}, 53 \%, 72 \mathrm{mg} ;{ }^{1} \mathrm{H}$ NMR $\left(400 \mathrm{MHz}, \mathrm{D}_{2} \mathrm{O}\right) \delta 6.12(\mathrm{~d}$, $\left.J=3.2 \mathrm{~Hz}, 1 \mathrm{H}, \mathrm{H}-1^{\prime}\right), 4.69-4.66\left(\mathrm{~m}, 1 \mathrm{H}, \mathrm{H}-2^{\prime}\right), 4.45-4.42(\mathrm{~m}, 1 \mathrm{H}$, $\left.\mathrm{H}-3^{\prime}\right), 4.37-4.34$ (m, 1H, H-4' ), 4.23-4.18 (m, 1H, H-5'), 4.08-4.03 $\left(\mathrm{m}, 1 \mathrm{H}, \mathrm{H}-5^{\prime \prime}\right), 4.06\left(\mathrm{~s}, 3 \mathrm{H}, \mathrm{N} 7-\mathrm{CH}_{3}\right), 3.54(\mathrm{t}, J=8.0 \mathrm{~Hz}, 2 \mathrm{H}$, $\left.\mathrm{NHCH}_{2}\right), 2.35(\mathrm{t}, J=2.6 \mathrm{~Hz}, 1 \mathrm{H}, \mathrm{CCH}), 2.30-2.26(\mathrm{~m}, 2 \mathrm{H}$, $\mathrm{NHCH}_{2} \mathrm{CH}_{2} \mathrm{CH}_{2}$ ), 1.83 (quin, $J=6.8 \mathrm{~Hz}, 2 \mathrm{H}, \mathrm{NHCH}_{2} \mathrm{CH}_{2} \mathrm{CH}_{2}$ ); ${ }^{31} \mathrm{P}$ NMR $\left(283 \mathrm{MHz}, \mathrm{D}_{2} \mathrm{O}\right) \delta 1.742 ; \mathrm{m} / \mathrm{z}:(\mathrm{M}+\mathrm{H})^{+}: 444.0418 ; \mathrm{t}_{\mathrm{R}}$ $15 \mathrm{~min}$.

\section{Procedure for the synthesis of mononucleotide cap analogs containing triazole ring ("click" reaction)}

Solution 1: $100 \mathrm{mg} \mathrm{CuSO}_{4} \times 5 \mathrm{H}_{2} \mathrm{O}$ in $10 \mathrm{~mL}$ of water; Solution 2: 10 $\mathrm{mg}$ of sodium ascorbate in $200 \mu \mathrm{L}$ of water.

To the suspension of mononucleotide derivatives $\mathbf{5 a}(0.0625$ mmol, $26 \mathrm{mg})$ or $\mathbf{5 b}(0.0625 \mathrm{mmol}, 27 \mathrm{mg})$ in anhydrous DMF $(2 \mathrm{~mL})$, solution $1(80 \mu \mathrm{L})$, TBTA $(0.00416 \mathrm{mmol}, 2.2 \mathrm{mg})$, solution $2(38 \mu \mathrm{L})$, and appropriate azide $(0.125 \mathrm{mmol})$ (see Fig. 2) were 
added and stirred under argon atmosphere overnight at $60^{\circ} \mathrm{C}$. The next day reaction mixtures were terminated by the addition of EDTA $(0.01 \mathrm{mmol}, 4 \mathrm{~mL})$ in $0.1 \mathrm{~mL}$ of water. Final products were purified by ion-exchange chromatography on a DEAESephadex A-25 column using a linear 0-1 M TEAB gradient to produce compounds $\mathbf{6 a}-\mathbf{6 e}$ as TEA salts. Final nucleotides were additionally purified on a reversed-phase HPLC column. Compounds 6a-6e were lyophilized to yield:

$\mathrm{N}^{2}$-((1H-1,2,3-triazol-4-yl)methyl)-7-methylguanosine-5' -monophosphate (6a); $24 \mathrm{mg}, 86 \%$, ammonium salt; ${ }^{1} \mathrm{H}$ NMR $(400 \mathrm{MHz}$, $\left.\mathrm{D}_{2} \mathrm{O}\right) \delta 7.89\left(\mathrm{~s}, 1 \mathrm{H}\right.$, triazole), $6.07\left(\mathrm{~d}, J=3.3 \mathrm{~Hz}, 1 \mathrm{H}, \mathrm{H}-\mathrm{1}^{\prime}\right), 4.73$ (s, $\left.2 \mathrm{H}, \mathrm{NHCH}_{2}\right), 4.58-4.56\left(\mathrm{~m}, 1 \mathrm{H}, \mathrm{H}-2^{\prime}\right), 4.41-4.38(\mathrm{~m}, 1 \mathrm{H}, \mathrm{H}-$ $\left.3^{\prime}\right), 4.35-4.32\left(\mathrm{~m}, 1 \mathrm{H}, \mathrm{H}-4^{\prime}\right), 4.20-4.15(\mathrm{~m}, J=2.4 \mathrm{~Hz}, J=4.3$ $\left.\mathrm{Hz}, J=11.9 \mathrm{~Hz}, 1 \mathrm{H}, \mathrm{H}-5^{\prime}\right), 4.04-3.99(\mathrm{~m}, J=2.4 \mathrm{~Hz}, J=5.0 \mathrm{~Hz}$, $\left.J=11.9 \mathrm{~Hz}, 1 \mathrm{H}, \mathrm{H}-5^{\prime \prime}\right), 4.07$ (s, 3H, N7- $\left.\mathrm{CH}_{3}\right) ;{ }^{31} \mathrm{P}$ NMR $(162$ $\left.\mathrm{MHz}, \mathrm{D}_{2} \mathrm{O}\right) \delta 1.17 ; \mathrm{m} / \mathrm{z}:(\mathrm{M}+\mathrm{H})^{+}: 459.0882, \mathrm{t}_{\mathrm{R}} 11 \mathrm{~min}$.

$\mathrm{N}^{2}$-((1-benzyl-1H-1,2,3-triazol-4-yl)methyl)-7-methylguanosine$5^{\prime}$-monophosphate (6b); $31 \mathrm{mg}, 92 \%$, ammonium salt; ${ }^{1} \mathrm{H}$ NMR $\left(400 \mathrm{MHz}, \mathrm{D}_{2} \mathrm{O}\right) \delta 7.99(\mathrm{~s}, 1 \mathrm{H}$, triazole), 7.37-7.34 (m, $3 \mathrm{H}, \mathrm{Ph})$, 7.28-7.26 (m, 2H, Ph), $5.94\left(\mathrm{~d}, J=3.2 \mathrm{~Hz}, 1 \mathrm{H}, \mathrm{H}-1^{\prime}\right), 5.56$ (s, $2 \mathrm{H}$, $\left.\mathrm{NCH}_{2} \mathrm{Ph}\right), 4.66\left(\mathrm{~s}, 2 \mathrm{H}, \mathrm{NHCH}_{2}\right), 4.54-4.52\left(\mathrm{~m}, 1 \mathrm{H}, \mathrm{H}-2^{\prime}\right), 4.38-$ $4.36\left(\mathrm{~m}, 1 \mathrm{H}, \mathrm{H}-3^{\prime}\right), 4.34-4.31\left(\mathrm{~m}, 1 \mathrm{H}, \mathrm{H}-4^{\prime}\right), 4.21-4.17$ ( $\mathrm{m}, J=2.4$ $\mathrm{Hz}, J=4.4 \mathrm{~Hz}, J=12.0 \mathrm{~Hz}, 1 \mathrm{H}, \mathrm{H}-5^{\prime}$ ), 4.02-4.05 (m overlapped with $\left.\mathrm{N} 7-\mathrm{CH}_{3}, 1 \mathrm{H}, \mathrm{H}-5^{\prime \prime}\right), 4.03$ (s, 3H, N7- $\left.\mathrm{CH}_{3}\right),{ }^{31} \mathrm{P}$ NMR (162 $\left.\mathrm{MHz}, \mathrm{D}_{2} \mathrm{O}\right) \delta 0.61 ; \mathrm{m} / \mathrm{z}:(\mathrm{M}+\mathrm{H})^{+}: 549.1570, \mathrm{t}_{\mathrm{R}} 16 \mathrm{~min}$.

N2-((1-(3-(2,6-dimethoxyphenoxy)propyl)-1H-1,2,3-triazol-4-yl) methyl)-7-methylguanosine-5'-monophosphate (6c); $33 \mathrm{mg}, 82 \%$, ammonium salt; ${ }^{1} \mathrm{H}$ NMR $\left(400 \mathrm{MHz}, \mathrm{D}_{2} \mathrm{O}\right) \delta 8.10$ (s, $1 \mathrm{H}$, triazole), $6.95(\mathrm{t}, J=8.4 \mathrm{~Hz}, 1 \mathrm{H}, \mathrm{Ph}), 6.47(\mathrm{~d}, J=8.4 \mathrm{~Hz}, 2 \mathrm{H}, \mathrm{Ph}), 5.86$ (d, $J$ $\left.=3.3 \mathrm{~Hz}, 1 \mathrm{H}, \mathrm{H}-1^{\prime}\right), 4.67-4.61\left(\mathrm{~m}, 3 \mathrm{H}, \mathrm{H}-2^{\prime}, \mathrm{NCH}_{2}\right), 4.55(\mathrm{~m}, 2 \mathrm{H}$, $\left.\mathrm{NHCH}_{2}\right), 4.37-4.24\left(\mathrm{~m}, 2 \mathrm{H}, \mathrm{H}-3^{\prime}, \mathrm{H}-4^{\prime}\right), 4.28-4.23\left(\mathrm{~m}, 1 \mathrm{H}, \mathrm{H}-5^{\prime}\right)$, 4.09-4.05 (m, 1H, H-5"), 3.95 (s, 3H, N7-CH $), 3.87-3.72(\mathrm{~m}, 2 \mathrm{H}$, $\mathrm{CH}_{2} \mathrm{O}$ ), 3.66 (s, $\left.6 \mathrm{H}, \mathrm{OCH}_{3}\right), 2.38-2.32\left(\mathrm{~m}, 2 \mathrm{H}, \mathrm{CH}_{2} \mathrm{CH}_{2} \mathrm{CH}_{2}\right) ;{ }^{31} \mathrm{P}$ NMR $\left(162 \mathrm{MHz}, \mathrm{D}_{2} \mathrm{O}\right) \delta 0.17 ; \mathrm{m} / \mathrm{z}:(\mathrm{M}+\mathrm{H})^{+}: 653.0789, \mathrm{t}_{\mathrm{R}} 13 \mathrm{~min}$.

$\mathrm{N}^{2}$-((1-(3-phenoxypropyl)-1H-1,2,3-triazol-4-yl)methyl)-7methylguanosine-5'-monophosphate (6d); $32 \mathrm{mg}, 88 \%$, ammonium salt; ${ }^{1} \mathrm{H}$ NMR $\left(400 \mathrm{MHz}, \mathrm{D}_{2} \mathrm{O}\right) \delta 8.00$ (s, 1H, triazol), 7.05$7.01(\mathrm{~m}, 2 \mathrm{H}, \mathrm{Ph}), 6.80-6.75(\mathrm{~m}, 1 \mathrm{H}, \mathrm{Ph}), 6.51-6.48(\mathrm{~m}, 2 \mathrm{H}, \mathrm{Ph})$, $5.88\left(\mathrm{~d}, J=2.9 \mathrm{~Hz}, 1 \mathrm{H}, \mathrm{H}-1^{\prime}\right), 4.65-4.62(\mathrm{t}, J=6.1 \mathrm{~Hz}, 2 \mathrm{H}$, $\left.\mathrm{NCH}_{2}\right), 4.55\left(\mathrm{~s}, 2 \mathrm{H}, \mathrm{NHCH}_{2}\right), 4.45-4.43\left(\mathrm{~m}, 1 \mathrm{H}, \mathrm{H}-2^{\prime}\right), 4.38-$ $4.36\left(\mathrm{~m}, 2 \mathrm{H}, \mathrm{H}-3^{\prime}, \mathrm{H}-4^{\prime}\right), 4.25-4.21\left(\mathrm{~m}, 1 \mathrm{H}, \mathrm{H}-5^{\prime}\right), 4.09-4.04(\mathrm{~m}$, $\left.1 \mathrm{H}, \mathrm{H}-5^{\prime \prime}\right), 4.02\left(\mathrm{~s}, 3 \mathrm{H}, \mathrm{N} 7-\mathrm{CH}_{3}\right), 3.87-3.72\left(\mathrm{~m}, 2 \mathrm{H}, \mathrm{CH}_{2} \mathrm{O}\right)$, 2.31-2.26 (m, 2H, $\left.\mathrm{CH}_{2} \mathrm{CH}_{2} \mathrm{CH}_{2}\right) ;{ }^{31} \mathrm{P}$ NMR $\left(162 \mathrm{MHz}, \mathrm{D}_{2} \mathrm{O}\right) \delta$ $0.70 ; \mathrm{m} / \mathrm{z}:(\mathrm{M}+\mathrm{H})^{+}: 593.1526, \mathrm{t}_{\mathrm{R}} 13.5 \mathrm{~min}$.

$\mathrm{N}^{2}$-(3-(1-benzyl-1H-1,2,3-triazol-4-yl)propyl)-7-methylguanosine-5'-monophosphate $(6 \mathrm{e}) ; 32 \mathrm{mg}, 91 \%$, ammonium salt; ${ }^{1} \mathrm{H}$ NMR (400 MHz, $\left.\mathrm{D}_{2} \mathrm{O}\right) \delta 7.77$ (s, $1 \mathrm{H}$, triazole), 7.39-7.35 (m, 3H, $\mathrm{Ph}$ ), 7.29-7.27 (m, 2H, Ph), 6.00 (d, J=3.3 Hz, 1H, H-1'), 5.52 (s, $\left.2 \mathrm{H}, \mathrm{CH}_{2} \mathrm{Ph}\right), 4.61-4.58\left(\mathrm{~m}, 1 \mathrm{H}, \mathrm{H}-2^{\prime}\right), 4.43-4.40(\mathrm{~m}, 1 \mathrm{H}$, $\left.\mathrm{H}-3^{\prime}\right), 4.35-3.33\left(\mathrm{~m}, 1 \mathrm{H}, \mathrm{H}-4^{\prime}\right), 4.23-4.18\left(\mathrm{~m}, 1 \mathrm{H}, \mathrm{H}-5^{\prime}\right), 4.08-$ $4.03\left(\mathrm{~m}, 1 \mathrm{H}, \mathrm{H}-5^{\prime \prime}\right), 4.06\left(\mathrm{~s}, 3 \mathrm{H}, \mathrm{N} 7-\mathrm{CH}_{3}\right), 3.43-3.39(\mathrm{t}, J=6.5$ $\left.\mathrm{Hz}, 2 \mathrm{H}, \mathrm{NHCH}_{2}\right), 2.78-2.75\left(\mathrm{t}, J=7.1 \mathrm{~Hz}, 2 \mathrm{H}, \mathrm{NHCH}_{2} \mathrm{CH}_{2} \mathrm{CH}_{2}\right.$ ), 2.04-1.92 (m, 2H, $\left.\mathrm{NHCH}_{2} \mathrm{CH}_{2} \mathrm{CH}_{2}\right) ;{ }^{31} \mathrm{P}$ NMR $\left(162 \mathrm{MHz}, \mathrm{D}_{2} \mathrm{O}\right)$ $\delta 0.68 ; \mathrm{m} / \mathrm{z}:(\mathrm{M}+\mathrm{H})^{+}: 577.1842 ; \mathrm{t}_{\mathrm{R}} 13 \mathrm{~min}$.

\section{Procedure for the synthesis of a dinucleotide cap analog (7)}

$\mathrm{P}^{1}-\mathrm{N}^{2}$-((1-benzyl-1H-1,2,3-triazol-4-yl)methyl)-7-methylguanosine$5^{\prime}-\mathrm{P}^{3}$-guanosine- $5^{\prime}$-triphosphate $(7)$ :
7-Methylguanosine 5'-diphosphate imidazolide (25,8 mg, 0.05 $\mathrm{mmol}$ ) and $\mathrm{ZnCl}_{2}(33 \mathrm{mg}, 0.24 \mathrm{mmol})$ were stirred in anhydrous DMF $(0.7 \mathrm{~mL})$ with compound $6 \mathrm{~b}(33 \mathrm{mg}, 0.06 \mathrm{mmol}$, TEA salt) at room temperature for $24 \mathrm{~h}$. The reaction mixture was poured into a solution of EDTA $(114 \mathrm{mg}, 0.3 \mathrm{mmol})$ in water $(1.5 \mathrm{~mL})$ and neutralized to $\mathrm{pH} 7$ by addition of $1 \mathrm{M}$ TEAB. The product was separated from the reaction mixture by chromatography on DEAE-Sephadex using a 0-1.0 M gradient of TEAB. Compound 7 was obtained as colorless crystals $(26 \mathrm{mg}, 0.025 \mathrm{mmol}, 42 \%$, TEA salt). The final dinucleotide cap analogs were additionally purified on a reversed-phase HPLC column. Compound 7 was lyophilized to yield: $26 \mathrm{mg}(0.025 \mathrm{mmol}), 42 \%$, ammonium salt; ${ }^{1} \mathrm{H}$ NMR (400 MHz, $\left.\mathrm{D}_{2} \mathrm{O}\right) \mathrm{m}^{7} \mathrm{G}: \delta 8.00(\mathrm{~s}, 1 \mathrm{H}$, triazole) $7.92(\mathrm{~s}, 1 \mathrm{H}, \mathrm{H} 8$ [G]), 7.33-7.29 (m, 3H, Ph), 7.24-7.22 (m, 2H, Ph), $5.78(\mathrm{~d}, 1 \mathrm{H}$, $\left.J=3.0 \mathrm{~Hz}, \mathrm{H}-\mathrm{1}^{\prime}\left[\mathrm{m}^{7} \mathrm{G}\right]\right), 5.72\left(\mathrm{~d}, J=6.1 \mathrm{~Hz}, 1 \mathrm{H}, \mathrm{H}-1^{\prime}[\mathrm{G}]\right), 5.52$ (s, $\left.2 \mathrm{H}, \mathrm{PhCH}_{2}\right), 4.66-4.55\left(\mathrm{~m}, 4 \mathrm{H}, \mathrm{H}-2^{\prime}[\mathrm{G}], \mathrm{H}-2^{\prime}\left[\mathrm{m}^{7} \mathrm{G}\right]\right.$, $\left.\mathrm{NHCH}_{2}\right), 4.42-4.20\left(\mathrm{~m}, 8 \mathrm{H}, \mathrm{H}-3^{\prime}[\mathrm{G}], \mathrm{H}-3^{\prime}\left[\mathrm{m}^{7} \mathrm{G}\right], \mathrm{H}-4^{\prime}[\mathrm{G}], \mathrm{H}-4^{\prime}\right.$ $\left.\left[\mathrm{m}^{7} \mathrm{G}\right], \mathrm{H}-5^{\prime}[\mathrm{G}], \mathrm{H}-5^{\prime}\left[\mathrm{m}^{7} \mathrm{G}\right], \mathrm{H}-5^{\prime \prime}[\mathrm{G}], \mathrm{H}-5^{\prime \prime}\left[\mathrm{m}^{7} \mathrm{G}\right]\right), 3.99$ $\left(\mathrm{s}, 3 \mathrm{H}, \mathrm{N} 7-\mathrm{CH}_{3}\right) ;{ }^{31} \mathrm{P}$ NMR $\left(162 \mathrm{MHz}, \mathrm{D}_{2} \mathrm{O}\right) \delta-11.64\left(2 \mathrm{P}, \mathrm{P}_{\alpha, \gamma}\right)$, $-23.23\left(1 \mathrm{P}, \mathrm{P}_{\beta}\right) \mathrm{m} / \mathrm{z}:(\mathrm{M}+\mathrm{H})^{+}: 974.0634$.

\section{SUPPLEMENTAL MATERIAL}

Supplemental material is available for this article.

\section{ACKNOWLEDGMENTS}

This work was supported by grants from the National Science Centre, Poland (DEC-2012/05/N/ST5/01367, DEC-2013/11/B/ ST5/02226, and UMO-2013/08/A/NZ1/00866) and from the National Center of Research and Development, Poland (02/EuroNanoMed/2011).

Received May 2, 2014; accepted July 14, 2014.

\section{REFERENCES}

Amblard F, Cho JH, Schinazi RF. 2009. Cu(I)-catalyzed Huisgen azide-alkyne 1,3-dipolar cycloaddition reaction in nucleoside, nucleotide, and oligonucleotide chemistry. Chem Rev 109: 4207-4220.

Ami T, Fujimoto K. 2008. Click chemistry as an efficient method for preparing a sensitive DNA probe for photochemical ligation. ChemBioChem 9: 2071-2074.

Cai A, Jankowska-Anyszka M, Centers A, Chlebicka L, Stepinski J, Stolarski R, Darzynkiewicz E, Rhoads RE. 1999. Quantitative assessment of mRNA cap analogues as inhibitors of in vitro translation. Biochemistry 38: 8538-8547.

Carberry SE, Darzynkiewicz E, Stepinski J, Tahara SM, Rhoads RE, Goss DJ. 1990. A spectroscopic study of the binding of N-7-substituted cap analogues to human protein synthesis initiation factor 4E. Biochemistry 29: 3337-3341.

Chan TR, Hilgraf R, Sharpless KB, Fokin W. 2004. Polytriazoles as copper(I)-stabilizing ligands in catalysis. Org Lett 6: 2853-2855.

Clemens MJ, Bommer UA. 1999. Translational control: the cancer connection. Int J Biochem Cell Biol 31: 1-23.

Darzynkiewicz E, Ekiel I, Tahara SM, Seliger LS, Shatkin AJ. 1985. Chemical synthesis and characterization of 7-methylguanosine cap analogs. Biochemistry 24: 1701-1707.

De Benedetti A, Graff JR. 2004. eIF-4E expression and its role in malignancies and metastases. Oncogene 23: 3189-3199.

De las Heras FG, Alonso R, Alonso GJ. 1979. Alkylating nucleosides 1. Synthesis and cytostatic activity of N-glycosyl(halomethyl)- 
1,2,3-triazoles. A new type of alkylating agent. J Med Chem 22: 496-501.

El-Sagheer AH, Brown T. 2010. Click chemistry with DNA. Chem Soc Rev 39: 1388-1405.

Furuichi Y, Shatkin AJ. 2000. Viral and cellular mRNA capping: past and prospects. Adv Virus Res 55: 135-184.

Ghosh P, Park C, Peterson MS, Bitterman PB, Polunovsky VA, Wagner CR. 2005. Synthesis and evaluation of potential inhibitors of eIF4E cap binding to 7-methyl GTP. Bioorg Med Chem Lett 15: 2177-2180.

Gingras AC, Raught B, Sonenberg N. 1999. eIF4 initiation factors: effectors of mRNA recruitment to ribosomes and regulators of translation. Annu Rev Biochem 68: 913-963.

Grudzien E, Stepinski J, Jankowska-Anyszka M, Stolarski R, Darzynkiewicz E, Rhoads RE. 2004. Novel cap analogs for in vitro synthesis of mRNAs with high translational efficiency. RNA 10: 1479-1487.

Hein JE, Fokin VV. 2010. Copper-catalyzed azide-alkyne cycloaddition (CuAAC) and beyond: new reactivity of copper(I) acetylides. Chem Soc Rev 39: 1302-1315.

Huang ZH, Zhuo ST, Li CY, Xie HT, Li D, Tan JH, Ou TM, Huang ZH, Gu LQ, Huang SL. 2013. Design, synthesis and biological evaluation of novel mansonone $\mathrm{E}$ derivatives prepared via CuAAC click chemistry as topoisomerase II inhibitors. Eur J Med Chem 68: 58-71.

Jankowska-Anyszka M, Piecyk K, Šamonina-Kosicka J. 2011. Synthesis of a new class of ribose functionalized dinucleotide cap analogues for biophysical studies on interaction of cap-binding proteins with the $5^{\prime}$ end of mRNA. Org Biomol Chem 9: 5564-5572.

Jia Y, Chiu TL, Amin EA, Polunovsky V, Bitterman PB, Wagner CR. 2010. Design, synthesis and evaluation of analogs of initiation factor 4E (eIF4E) cap-binding antagonist Bn7-GMP. Eur J Med Chem 45: 1304-1313.

Johnson JA Jr, Thomas HJ, Schaeffer HJ. 1958. Synthesis of potential anticancer agents. XIII. Ribosides of 6-substituted purines. J Am Chem Soc 80: 699-702.

Johnson EA, Marks RS, Mandrekar SJ, Hillman SL, Hauge MD, Bauman MD, Wos EJ, Moore DF, Kugler JW, Windschitl HE, et al. 2008. Phase III randomized, double-blind study of maintenance CAI or placebo in patients with advanced non-small cell lung cancer (NSCLC) after completion of initial therapy (NCCTG 97-24-51). Lung Cancer 60: 200-207.

Kadokura M, Wada T, Urashima C, Sekine M. 1997. Efficient synthesis of $\gamma$-methyl-capped guanosine $5^{\prime}$-triphosphate as a $5^{\prime}$-terminal unique structure of U6 RNA via a new triphosphate bond formation involving activation of methyl phosphorimidazolide using $\mathrm{ZnCl}_{2}$ as catalyst in DMF under anhydrous conditions. Tetrahedron Lett 38: 8359-8362.

Kowalska J, Lukaszewicz M, Zuberek J, Ziemniak M, Darzynkiewicz E, Jemielity J. 2009. Phosphorothioate analogs of $\mathrm{m}^{7} \mathrm{GTP}$ are enzymatically stable inhibitors of cap-dependent translation. Bioorg Med Chem Lett 19: 1921-1925.

Lakshman MK, Singh MK, Parrish MK, Balachandran R, Day BW. 2010. Azide-tetrazole equilibrium of C-6 azidopurine nucleosides and their ligation reactions with alkynes. J Org Chem 75: 2461-2473.

Lewis JD, Izaurralde E. 1997. The role of the cap structure in RNA processing and nuclear export. Eur J Biochem 247: 461-469.

Mamane Y, Petroulakis E, Rong L, Yoshida K, Ler LW, Sonenberg N. 2004. eIF4E - from translation to transformation. Oncogene 23: 3172-3179.

Marcotrigiano J, Gingras AC, Sonenberg N, Burley SK. 1997. Cocrystal structure of the messenger RNA $5^{\prime}$ cap-binding protein (eIF4E) bound to 7-methyl-GDP. Cell 89: 951-961.
Matsuo H, Li H, McGuire AM, Fletcher CM, Gingras AC, Sonenberg N, Wagner G. 1997. Structure of translation factor eIF4E bound to $\mathrm{m}^{7} \mathrm{GDP}$ and interaction with $4 \mathrm{E}-$ binding protein. Nat Struct Biol 4: 717-724.

Niedzwiecka A, Marcotrigiano J, Stepinski J, Jankowska-Anyszka M, Wyslouch-Cieszynska A, Dadlez M, Gingras AC, Mak P, Darzynkiewicz E, Sonenberg N, et al. 2002. Biophysical studies of eIF4E cap-binding protein: recognition of mRNA $5^{\prime}$ cap structure and synthetic fragments of eIF4G and 4E-BP1 proteins. J Mol Biol 319: 615-635.

Piecyk K, Davis RE, Jankowska-Anyszka M. 2012. Synthesis of $N^{2}$-modified 7-methylguanosine $5^{\prime}$-monophosphates as nematode translation inhibitors. Bioorg Med Chem 20: 4781-4789.

Rhoads RE. 1985. The cap structure of eukaryotic messenger RNA and its interaction with cap-binding protein. Prog Mol Subcell Biol 9: 104-155.

Rhoads RE. 2009. eIF4E: new family members, new binding partners, new roles. J Biol Chem 284: 16711-16715.

Seela F, Sirivolu VR. 2008. Pyrrolo-dC oligonucleotides bearing alkynyl side chains with terminal triple bonds: synthesis, base pairing and fluorescent dye conjugates prepared by the azide-alkyne "click" reaction. Org Biomol Chem 6: 1674-1687.

Seela F, Sirivolu VR, Chittepu P. 2008. Modification of DNA with octadiynyl side chains: synthesis, base pairing, and formation of fluorescent coumarin dye conjugates of four nucleobases by the alkyne-azide "click" reaction. Bioconjug Chem 19: 211-224.

Sharp PA. 1994. Split genes and RNA splicing. Cell 77: 805-815.

Shen X, Tomoo K, Uchiyama S, Kobayashi Y, Ishida T. 2001. Structural and thermodynamic behavior of eukaryotic initiation factor $4 \mathrm{E}$ in supramolecular formation with 4E-binding protein 1 and mRNA cap analogue, studied by spectroscopic methods. Chem Pharm Bull (Tokyo) 49: 1299-1303.

Soltis MJ, Yeh HJ, Cole KA, Whittaker N, Wersto RP, Kohn EC. 1996. Identification and characterization of human metabolites of CAI [5-amino-1-1 (4'-chlorobenzoyl-3,5-dichlorobenzyl)-1,2,3-triazole4-carboxamide). Drug Metab Dispos 24: 799-806.

Sonenberg N. 1996. mRNA 5' cap-binding protein eIF4E and control of cell growth. In Translational control (ed. Hershey JWB, et al.), pp. 245-269. Cold Spring Harbor Laboratory Press, Cold Spring Harbor, NY.

Stepinski J, Waddell C, Stolarski R, Darzynkiewicz E, Rhoads RE. 2001. Synthesis and properties of mRNAs containing the novel "anti-reverse" cap analogs 7-methyl(3'-O-methyl)GpppG and 7-methyl (3'-deoxy)GpppG. RNA 7: 1486-1495.

Temple C Jr, Thorpe MC, Coburn WC Jr, Montgomery JA. 1966a. Studies on the azidoazomethine-tetrazole equilibrium. IV. Azidopurines. J Org Chem 31: 935-938.

Temple C Jr, Kussner CL, Montgomery JA. 1966b. Studies on the azidoazomethine-tetrazole equilibrium. V. 2- and 6-azidopurines. J Org Chem 31: 2210-2215.

Tron GC, Pirali T, Billington RA, Canonico PL, Sorba G, Genazzani AA. 2008. Click chemistry reactions in medicinal chemistry: applications of the 1,3-dipolar cycloaddition between azides and alkynes. Med Res Rev 28: 278-308.

Yoshikawa M, Kato T, Takenishi T. 1967. A novel method for phosphorylation of nucleosides to $5^{\prime}$-nucleotides. Tetrahedron Lett 8: 5065-5068.

Ziemniak M, Strenkowska M, Kowalska J, Jemielity J. 2013. Potential therapeutic applications of RNA cap analogs. Future Med Chem 5: $1141-1172$. 


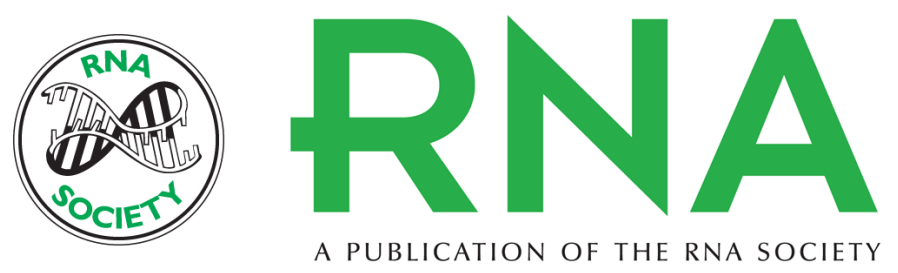

\section{Triazole-containing monophosphate mRNA cap analogs as effective translation inhibitors}

Karolina Piecyk, Maciej Lukaszewicz, Edward Darzynkiewicz, et al.

RNA 2014 20: 1539-1547 originally published online August 22, 2014

Access the most recent version at doi:10.1261/rna.046193.114

\section{Supplemental http://rnajournal.cshlp.org/content/suppl/2014/08/05/rna.046193.114.DC1 Material \\ References This article cites 42 articles, 4 of which can be accessed free at: http://rnajournal.cshlp.org/content/20/10/1539.full.html\#ref-list-1 \\ Creative This article is distributed exclusively by the RNA Society for the first 12 months after the Commons full-issue publication date (see http://rnajournal.cshlp.org/site/misc/terms.xhtml). After 12 License months, it is available under a Creative Commons License (Attribution-NonCommercial 4.0 International), as described at http://creativecommons.org/licenses/by-nc/4.0/.}

\section{Email Alerting Receive free email alerts when new articles cite this article - sign up in the box at the top} Service right corner of the article or click here. 